DOI 10.32370/IA_2019_01_7

UDK 783:378.147(477)

\title{
"Solemn Liturgy" Lesya Dychko - Masterpiece of Ukrainian Choral Music (Pedagogical Considerations)
}

\author{
Yudin Andriy \\ Chair of Academic and Solo Vocal \\ Institute of Arts Borys Grinchenko Kyiv University (Kyiv, Ukraine)
}

\begin{abstract}
Lesya Dychko wrote opus "Solemn Liturgy of St. John Chrysostom"in 1999 for soloists and mixed choir a capella. In general, the composer wrote three modern liturgies in Ukrainian. Such an act is a manifestation of patriotism, the mental depth of her soul, spirituality, philosophical worldview. Lesya Dychko continues the tradition of liturgies of Ukrainian composers Nikolay Dyletskyi, Maxim Berezovskyi, Dmitryi Bortnyanskyi, Artemii Vedel', Yevhen Stankovich, Myroslav Skoryk. Her "Solemn Liturgy" consists of 20 completed fragments, in which the author adheres to the liturgical canons. Lesya Dychko's liturgy has three options for a contemporary work: the individual compositional technique, folklore orientation, and semantic loading of the choir textures (traditional baroque musical rhetorical figures). Their comprehension and assimilation in musical practice will enrich the professional resources of the future specialist, provide a solid intellectual basis of activity. This is dormouse technique, vivid phonism, colorful sound of chords, kluster consonance. Another interesting modern technique of composer is the aleatory, improvisational, symbiotic and collage polystylistics, aleatory. The neofolklore component of the liturgy style is manifested in the means of musical expression, which are characteristic of folklore: the lack of number of voices, order variability, parallel motion of voices in pure intervals; episodes in the non-wide range, as well as the free size that is subject to the text. From the era of Baroque Lesya Dychko's musical rhetorical figures and symbols.

Key words: liturgy, traditions, sacred music, modern composition, harmony, monody, musical folklore, genre, synthesis, Dychko.

Постановка проблеми. Духовній музиці у сучасному суспільстві відводиться значне місце. Леся Василівна Дичко - перша композиторка в Україні, що внесла в суворий канон церковної літургійної музики певні новації, які стосуються колористики барв сучасної гармонії (сонористики), засобів поліфонії та особливого вокального озвучування молитов. Цим вона зробила неймовірний прорив, повністю модернізувавши українську духовну хорову музику у природній ій неофольклорні стилістиці.

У хоровому класі мистецького ВНЗ необхідною умовою є розширення образностильових горизонтів репертуару - музики, яку майбутній виконавець та викладач практично опановує. В Літургії Лесі Дичко наявні три параметри сучасного твору індивідуальна техніка композиції, фольклорна орієнтація стилю та семантична навантаженість хорової фактури (традиційні барокові музично-риторичні фігури). Їх
\end{abstract}


осмислення та засвоєння у музично-практичній діяльності збагатить професійні ресурси майбутнього фахівця, надасть міцне інтелектуальне підгрунтя діяльності.

Аналіз останніх досліджень і публікацій. Творчість Л. Дичко привертає увагу багатьох дослідників, але їі духовна хорова музика досі не стала об'єктом спеціального дослідження. Окремі сторінки, що торкаються проблеми статті містить монографія С. Гриці [1]. Третій розділ навчального посібника О. Письменної [3, с. 97-148] зосереджений на аналізі «Урочистої літургії» у теологічній площині, тому вкрай необхідним видається заповнити цю лакуну.

Мета статті - аналітична характеристика хорової партитури «Урочистої літургії» Лесі Дичко, де особлива увага буде спрямована на музичні засоби виразності провідного твору духовної музики сучасності. Цій меті підпорядковано декілька завдань, тобто: 1) систематизувати відомості про духовні хорові твори Лесі Дичко у контексті історичного шляху української літургії; 2) надати образну характеристику провідним номерам літургії та засобам вираження урочистої та оптимістичної іiі концепції; 3)окреслити стилістичні засади духовної музики Л. Дичко; 4) констатувати традиції та новації у прочитанні жанру літургії.

Виклад основного матеріалу. У доробку Лесі Дичко саме духовні хорові жанри посідають істотне місце. Ї̈̈ Перша літургія (для однорідного хору) була задумана у 1980ті, написана в 1990 році, в цьому ж році була закінчена і Друга - для мішаного хору. У 1999 році була написана «Урочиста літургія святого Іоанна Златоустого» для мішаного хору, у 2002 році Літургія для дитячого хору, Духовні твори для солістів і органа, серед яких «Благослови, душе моя, Господи», «Отче наш», «Тобі співаємо», «Хваліть Господа с небес».

Звернення Лесі Дичко до такого серйозного жанру є проявом неймовірної глибини іiі душі, духовності і філософського світобачення, адже, жінка-композитор, яка вирішує подібні масштабні завдання, реалізовує високу місію, духовно оберігає рідну землю, неначе богоматір Оранта великої Софії Київської. Саме церковні твори та літургії принесли композиторці найбільшу славу.

Відповідно до теоцентричного світогляду, музика була знаком Божої слави, їі церковний канон наслідував особливості співів ангелів в Віфлеємі - провозвісників народження Христа. Уподібнюючись ангелогласному співу Свангельського прообразу, 
літургійні мелодії в обряді, де панували сакральні категорії з ідеями позачасового і вічного, повинні були зберігати особливий характер. У монодійному мелосі давніх літургій не було ані динамічної спрямованості, ні енергії ритму, ані гострих ладових тяжінь. Мовою служби була латинь, яку сприймали як мову «чисту», віддалену від прийнятої в світі мови. Починаючи з ХІХ століття, в українській духовній музиці стався дуже важливий перелом, який надалі прямо вплинув на розвиток літургії як жанру. М. Леонтович разом зі К. Стеценком, М. Вериківським та О. Кошицем, створив основний масив сакральних піснеспівів, який є фундаментом української національної школи. Духовні твори видатних композиторів базуються на українській фольклорній основі, що є характерною особливістю українського духовно-музичного мистецтва початку ХХ ст.; на цей факт вказує М. Юрченко [3, с.9]. Доречно сказати, що багато українських композиторів також зверталися до написання Літургії св. Іоанна Златовустого: Микола Дилецький, Максим Березовський, Дмитро Бортнянський, Артемій Ведель, у наші часи це Свген Станкович (2003), Мирослав Скорик (2005) і звісно Леся Дичко. Її «Урочиста Літургія» для солістів та мішаного хору a capella (1999, 2 редакція у 2002 році) складається із 22 завершених номерів, у яких авторка дотримується богослужбових канонів. Усі тексти диякона та хору викладено українською мовою.

У хоровому класі мистецького ЗВО ця музика, не дивлячись на їі складність, може займати важливе місце, як у концертному репертуарі хору, так і у курсі спеціальних дисциплін (історія хорової музики, фах). На нашу думку, у цій музиці Л. Дичко особливо виявляється тенденція тяжіння до світлих образів, що розкриває іï світогляд композитора-оптиміста, патріота, що прагне всією душею імплементувати в українську музику багато народних елементів (в образному, жанровому та інтонаційному плані). Яскравим зразком цього є iї «Урочиста Літургія», яка по-справжньому розкриває духовну аутентику українського народу, культуру - як минулого, так і сучасності.

Зосередимось на деяких особливостях структури та образів твору. Першій номер «Мирна єктенія» має темп та характер Maestoso, перемінний розмір (5/2, 4/2, 6/2, тональність Des-dur). Вже в перших акордах цього твору гармонічні кластери у партії хору на слові «Амінь» створюють звукозображальний ефект дзвонів. Хор у даному номері виконує допоміжну та фонову функцію до речитативу дяка. А світла гармонія надає особливого змісту цим важливим, благальним словам «Господи, помилуй» та 
піднесеного стану (акцент у слові «помилуй» припадає на альтерований субдомінантовий квінтсекстакорд (\#I)). Весь цей номер направлений на прохання у Бога щастя та миру для всіх людей. Завдяки постійній зміні гармонії на слові «помилуй» змінюється і його зміст, який від світлого прохання переходить до скорботного благання. Номер другий «Благослови, душе моя, Господа» у тональності Des-dur також має перемінний метр і розмір $(5 / 4,8 / 4,9 / 4,10 / 4,4 / 2,6 / 2)$, що веде до природнього невимушеного звучання хору. Тут переважає світле, небесне звучання у сопрано та альтів, які чергуються із монодичним хоралом у альтів та басів, а пізніше у тенорів і басів. У номері «Мала єктенія» диякон знову закликає прихожан до молитви, йому відповідають акордові переклички у хору між S. А. та Т. В., які поступово затихають та утворюють гармонічний фон для його речитації. №3 «Хвали, душе моя Господа» (Desdur, Allegretto) відрізняється світлою схвильованістю, піднесеністю емоційного стану. Перші два такти теми, яка проводиться у партії альтів та тенорів, завдяки акордовому викладенню (паралельними тризвуками), рівномірному чергуванні четвертних та восьмих тривалостей у старовинному розмірі 3/2, знову надає звукозображального ефекту. Подібний «передзвін святкових церковних дзвонів» стає тематичною аркою першого розділу і звучить радісно та урочисто. Розділ «Не надійтеся на князів, на тих синів людських»є контрастним від попереднього і створює образ прихованої журби, скорботи. [1, с. 164]. Закцентуємо, що музика прямо ілюструє настрій тексту, виникає новий темп (Sostenuto), похмура тональність gis-moll, унісонна тема у сопрано та альтів супроводжується тихою, педальною гармонічною підтримкою у тенорів та басів. Далі терцієві дублювання та низхідний рух паралельними тризвуками. №4 «Сдинородний сину» відкривається приглушеним архаїчним вступом у тенорів та басів. Таке звучання утворюється завдяки руху паралельними квінтами та квартами на словах «I нині i повсякчас, і на віки віків, Амінь». Тут вперше з'являється solo (молитовне прохання у сопрано). Особливістю цього розділу є повна відсутність визначеного метру; дихання береться відповідно до тексту, та за вказівкою автора (у нотах зображується комою, над нотним текстом). Неймовірної краси музика п’ятого номеру «У царстві твоїм» змушує поринути в світ звукового вихору, який все більше і більше закручує сяючими кластерними гармоніями. Тут є solo тенора та альта, яких хор підтримує нетерцієвими співзвуччями mormorando. У партії цих голосів звучить проповідь самого Бога, який 
каже: «Блаженні убогії духом, бо їх є Царство Небесне. Блаженні ті, що плачуть, бо вони втішаться...». №6 «Прийдіть, прийдіть» інтонаційно нагадує номер «Благослови душе моя Господа». Такі тематичні зв’язки і створюють цілісність всього твору. №7 «Святий Боже» відрізняється співучою, кантиленною мелодією у солюючого альта на фоні статичних акордів у партії хору та його середнього епізоду. №8 «Прокимен», №9 «Читання Апостола», №10 «Потрійна єктенія» (C-dur). Композиторка знову застосовує змінний розмір, який повністю підпорядковується сакральному тексту. №11 «Херувимська пісня» звучить soprano solo, тут згадуються небесні створіння: «...Його в славі проводять ангельські чини невидимо». Своєрідним є середній епізод Presto 3 №14 «Милість миру», який побудовано на алюзії відомого «Щедрика» Леонтовича. Симбіотична полістилістика (алюзія) тут поєднана з колажним іiі типом, бо декілька шарів фактури вільно імпровізують, респонсорно та безперервно повторюється на слово «Свят». Алеаторичний прийом композиторка застосовує саме на мажорний варіант поспівки «Щедрика» (Леонтович: c-h-c-a; Дичко e-d-e-c ). Завдяки цьому створюється урочиста та піднесена атмосфера частини і всього твору.

Висновки. Таким чином, Літургії Лесі Дичко притаманна сонористична техніка, яка направлена на утворення яскравого фонізму, барвистого звучання музики. В першу чергу це відбувається завдяки кластерним співзвуччям, які прикрашають твір. Ще один цікавий сучасний прийом композиторської техніки - це алеаторична імпровізаційність, завдяки якій музичне мереживо хорової тканини неначе дихає, рухається, є легким та польотним. По-друге, неофольклорна орієнтація стилю Літургії - ще одна іï родзинка. Композиторка використовує тут засоби музичної виразності, які характерні для фольклору: нестала кількість голосів, ладова мінливість, паралельний рух голосів чистими інтервалами; поспівки в неширокому діапазоні, а також вільний розмір, який безсумнівно підпорядковується тексту. 3 епохи бароко духовна музика має свої таємниці та символи: у творі Лесі Дичко можна спостерігати інтонації, які несуть семантичне значення: швидкі висхідні і низхідні рухи голосів - виражають політ ангелів (№6 «Співаємо Тобі»; номер «Алилуя», № 21 в Коді в момент перегукувань між жіночими і чоловічими партіями голосів на слова «На многії літа»); трелеподібний рух (як наприклад, в № 3 в момент імпровізаційного епізоду на слова «Хвали, душе моя», «Співатиму Богові моєму»; № 14 на слова «Свят» (алеаторичний прийом)) - нагадує 
сміх, веселощі; мотив спокути гріхів - це висхідна трьохступенева секвенція, яка базується на поступовому русі (№ 13, середній розділ Agitato, на слова «У славі судити живих і мертвих» - dis-e-fis, e-fis-gis; №14 на слова «Отцю і Сину» - es-f-ges, f-ges-as; №16 на словах «...у спокусу, але визволи...» - e-fis-g, fis-gis-a); висхідний тетрахорд осягнення волі Господньої (№5 на слова «Бо велика нагорода буде вам на Небесах», №8 на слова «Нехай буде, Господи, милість твоя на нас»,№9 на слова «Зміцнюйтеся Господом», №13 на слова «Вірую в єдиного Бога», в епізоді Recitativo «Що від Отця походить»).

Аналізуючи «Урочисту літургію» Л. Дичко, слухаючи іï звукові барви, переплетіння голосів, виконавець має повністю поринути всередину цих променів тепла і світла іiї духовної музики; при цьому особливою переконливістю сповнюється вислів Лесі Василівни: «Духовність - це найбагатший скарб людини, ії божественного єства».

\section{References}

1. Hrytsya, S. (2012). Lesya Dychko v zhytti i tvorchosti [Lesya Dychko in life and creativity]. Drohobych: Posvit. 272 p. (In Ukrainian).

2. Yurchenko, M. (Ed.). (2004). Dukhovna muzyka ukrayins'kykh kompozytoriv 20-kh rokiv XX st.. [Spiritual music of Ukrainian composers 20-th XX century]. Kyyiv: Ukrayins'kyy fond dukhovnoyi muzyky. 224 p. (In Ukrainian).

3. Pys'menna, O. (2010). Khorova muzyka Lesi Dychko [Lesya Dychko choral music]. L'viv: Naukove tovarystvo im. T. Shevchenka.268 p. (In Ukrainian). 